\section{Validity and reliability of self- reported weight and height measures for the diagnoses of adolescent's nutritional status}

\section{Validade e confiabilidade das medidas referidas de peso e estatura para o diagnóstico do estado nutricional de adolescentes}

\section{Carla Cristina Enes}

Priscila Maria Fúncia Fernandez

Silvia Maria Voci

Natacha Toral

Alexandre Romero

\section{Betzabeth Slater}

Department of Nutrition, School of Public Health, University of Sao Paulo, Sao Paulo, Brazil.

Author's individual contributions: Priscila Fernandez, Silvia Voci, Alexandre Romero, and Natacha Toral were responsible for data collection. Carla C. Enes, Priscila Fernandez, and Silvia Voci were responsible for statistical analysis, interpretation, and discussion of the results and for writing the manuscript. Natacha Toral, Alexandre Romero, and Betzabeth Slater collaborated in interpretation and discussion of the results and for writing the manuscript. In addition, Betzabeth Slater was responsible for the research design and coordinated the study.

Conflict of interest: none

Corresponding author: Carla Cristina Enes. Departamento de Nutrição da Faculdade de Saúde Pública da USP. Av. Dr. Arnaldo, 715 - Cerqueira César Sao Paulo, SP. Brazil - CEP 01246-904. E-mail: cenes@usp.br.

\section{Resumo}

Objetivo: Avaliar a validade do peso, estatura e Índice de Massa Corporal (IMC) referidos e sua confiabilidade para o diagnóstico do estado nutricional de adolescentes de Piracicaba. Métodos: Participaram do estudo 360 adolescentes de ambos os sexos, de escolas públicas de Piracicaba, com idade entre 10 e 15 anos. Os adolescentes autorelataram seu peso e estatura, sendo esses valores obtidos por medidas diretas, logo em seguida, pelos entrevistadores. A validade do IMC referido foi calculada segundo índices de sensibilidade, especificidade e valor preditivo positivo (VPP). Avaliou-se a concordância entre as categorias de IMC obtido por meio das medidas referidas e aferidas a partir do coeficiente kappa ponderado, coeficiente de correlação de Lin. e gráficos de Bland e Altman e Lin. Resultados: Verificou-se que tanto os meninos quanto as meninas subestimaram o peso $(-1,0 \mathrm{me}$ ninas e meninos) e a estatura (meninas $-1,2$ e meninos $-0,8)(p<0,001)$. Os valores de IMC aferidos e referidos apresentaram uma concordância moderada. A sensibilidade do IMC referido para classificar os indivíduos obesos foi maior para os meninos $(87,5 \%)$, enquanto a especificidade foi maior para as meninas (92,7\%). OVPP foi elevado somente para a classificação da eutrofia. Conclusões: As medidas referidas de peso e estatura de adolescentes não representam medidas válidas e, portanto, não devem ser usadas em substituição aos valores mensurados. Além disso, verificou-se que $10 \%$ dos meninos obesos e $40 \%$ das meninas obesas poderiam permanecer não identificados utilizando-se as medidas auto-referidas, confirmando a baixa validade das medidas auto-referidas.

Palavras-chave: Adolescente. Índice de Massa Corporal. Estado nutricional. Estudos de validação. 


\section{Abstract}

Purpose: To assess the validity and reliability of self-reported height, weight, and Body Mass Index (BMI) to diagnose the nutritional status of adolescents. Methods: The study included 360 public school students of both genders, with ages ranging from 10 to 15 years. Adolescents self-reported their weight and height, and these values were later obtained directly by interviewers. The validity of BMI based on self-reported measures was calculated using sensitivity and specificity indexes, and positive predictive value (PPV). Agreement between self-reported and measured BMI was evaluated using Kappa's weight coefficient, the Lin correlation coefficient, and Bland-Altman and Lin's plots. Results: Both girls and boys underestimated their weight ( -1.0 girls and boys) and height (girls -1.2 and boys -0.8 ) $(\mathrm{p}<0.001)$. BMI presented moderate agreement between measured and self-reported values. Sensitivity of estimated BMI based on reported measures to classify obese subjects was higher for boys (87.5\%) than it was for girls (60.9\%), whereas specificity was higher for girls (92.7\%) than it was for boys (80.6\%). PPV was high only for classification of normal-weight adolescents. Conclusions: Self-reported measures of weight and height in adolescents do not present valid measures; therefore, they should not be used to replace measured values. Additionally, we observed that $10 \%$ of obese boys and $40 \%$ of obese girls could have remained unidentified if we had used only self-reported measures, emphasizing the effects of the low reliability of self-reporting.

KeyWords: Adolescent. Body mass index. Nutritional status. Self-reported. Height. Validation studies.

\section{Introduction}

Nutritional epidemiological studies generally use anthropometric measures of weight and height, especially the Body Mass Index (BMI), to assess nutritional status and to monitor health and/or growth of subjects and populations. Thus, proper accuracy of anthropometric data is essential to correctly classify nutritional status ${ }^{1}$.

The advantages of using BMI are low cost, ease of measurement, and high reproducibility ${ }^{2,3}$. However, epidemiological studies have large samples, and direct assessment of weight and height may increase research costs, since they require training on anthropometrics and greater time availability. There are also difficulties due to the transportation of equipment to the field.

Thus, self-reported measures can be an alternative for epidemiological measurements, aiming at reducing cost and simplifying fieldwork ${ }^{4}$. Although most studies on self-reported measures of weight and height have been performed in adults, research with adolescents shows that self-reported data are highly correlated with measured data ${ }^{5-8}$. However, although reliability of self-reported data may be high, its validity is still uncertain.

The majority of the studies on validity of self-reported measures have samples of adult populations, and to date, only one report has been described in Brazil with adolescents ${ }^{7}$; this is a relevant study because little is known about the accuracy of these measures in the population of adolescents.

The objective of the present paper was to assess the validity of weight, height, and estimated BMI based on reported measures and their reliability to diagnose the nutritional status of adolescents in Piracicaba, a city in the State of São Paulo, Brazil, identifying demographic characteristics that may lead to information bias.

\section{Methods}

\section{Participants}

Data were used from a cohort study 
called "Dietary intake and physical activity as determinants for changes in body mass index of a cohort of adolescents from public schools in the city of Piracicaba, Sao Paulo*." The cross-sectional study (baseline) focused on adolescents of both genders with ages ranging from 10 and 15 years, studying in public schools in Piracicaba (SP). Interviews took place in school settings during classes, in November 2004. Permission to conduct the survey was obtained at school and from the adolescents' parents or guardians. Information on sample procedures was published in a previous study 9 .

\section{Data collection}

We interviewed 420 adolescents; those without self-reported weight and/or no self-reported height were excluded from the study. The final sample had 360 adolescents ( $86 \%$ of the initial sample).

Adolescents were asked by trained staff to self-report their weight (kilograms) and their height (centimeters), and then these measures were immediately assessed by interviewers. Participants were unaware that their actual height and weight would be subsequently verified.

Weight and height were measured twice by procedures standardized by Lohman et al. ${ }^{10}$. Students were weighed to the nearest $0.1 \mathrm{~kg}$ on a Tanita ${ }^{\circledR}$ electronic platform scale with a capacity of $150 \mathrm{~kg}$ and sensitivity of 100 grams. Height measures were made to the nearest centimeter with the help of a wooden stadiometer, mounted on a wall with no baseboards. Prior to measurement, students were asked to take off their shoes, heavy outer clothing, and personal items from their pockets.

To classify nutritional status, from Body Mass Index (BMI) calculated as weight $(\mathrm{kg}) /$ height $(\mathrm{m})^{2}$ we used cut-off points: < 3rd percentile: low weight; $\geq 3$ rd percentile and $<85$ th percentile: normal weight; $\geq 85^{\text {th }}$ percentile and $<97^{\text {th }}$ percentile: overweight; and $\geq 97^{\text {th }}$ percentile: obese, using the reference of the World Health Organization ${ }^{11}$.

Absolute error of weight, height, and BMI was estimated by the difference between self-reported and measured values (absolute error $=$ self-reported value - measured value). Negative differences indicate underestimation, and positive values represented overestimation.

\section{Statistical analysis}

We used Wilcoxon's test, considering the non-parametric nature of the variables, to examine the differences between self-reported and measured values for each subject according to gender and age. Mann-Whitney's U test was applied to compare absolute weight, height, and BMI error according to gender in the different age categories. Kruskal-Wallis' test was employed to assess the differences between selfreported and measured values according to the categories of age and nutritional status. The intra-class correlation coefficient (ICC) was also calculated.

BMI validity obtained from the reported measures of weight and height was calculated according to sensitivity and specificity indices and positive predictive value (PPV). Weighted kappa coefficient, Lin's correlation coefficient, and Bland-Altman ${ }^{12}$ and Lin's ${ }^{13}$ were used to assess the agreement between the reported and measured BMI categories. The alpha level was set at 0.05 . Stata software version 9 (StataCorp, College Station, TX 2001) and SPSS version 11.5 (Chicago, Marketing Department, 2002) were used for data management and statistical analyses.

The study was approved by the Ethical Research Committee of the School of Public Health, University of Sao Paulo.

\section{Results}

Among the 420 adolescents interviewed, $52.5 \%$ were girls. Among the 60 adolescents

* Project funded by Fundação de Amparo à Pesquisa do Estado de São Paulo - FAPESP process \# 02/9521-9 
excluded, $66.7 \%$ were under 12 years of age. Comparing the adolescents who were excluded with those studied, we observed significant differences for age and BMI $(\mathrm{p}<$ 0.001 ). Boys and girls underestimated their weight by about $1 \mathrm{~kg}(p<0.001)$ (Table 1$)$. Comparing absolute error among genders, there was no significant difference in any age group. Weight underestimation was more frequent among 13-year-old boys ( $p$ $=0.01$ ). Absolute errors of weight presented statistical significance for all age categories, in both genders, except for 14-year-old adolescents ( $p=0.10$ boys $v s$. $p=0.09$ girls).

Height was underestimated among girls and boys (-1.2 and -0.8 , respectively; $p<0.001$ ) (Table 1). There were differences between self-reported and measured values according to categories of age only in girls ( $p=0.01$ ). According to age categories, the greatest underestimation of height occurred among 12-year-old boys. Height was more accurately reported by older girls (14y). Around $4.0 \%$ of boys and $11.0 \%$ of girls selfreported this measure correctly.

BMIs based on self-reported data were higher than BMIs based on measured data $\left(0.21 \mathrm{~kg} / \mathrm{m}^{2}\right.$ for boys and $0.01 \mathrm{~kg} / \mathrm{m}^{2}$ for girls $)$, although with no statistical significance (Table 1). There was no significant difference between median BMI errors according to age categories.

We found significant differences between self-reported and measured weight according to categories of nutritional status. Weight was underestimated in all categories, except for underweight adolescents for both genders $(p<0.001)$. Obese adolescents reported this measure with higher differences (approximately $-6 \mathrm{~kg}$ boys and $-5 \mathrm{~kg}$ girls). Boys and girls underestimated their height regardless of nutritional status. However, the differences were significant only for boys ( $p=0.03$ ). Underweight adolescents selfreported height with greater discrepancy in comparison with assessed value $(-5.9 \mathrm{~cm}$ for boys and $-3.9 \mathrm{~cm}$ for girls). Differences between self-reported and assessed BMI also varied according to the nutritional status of adolescents $(p<0.001)$. BMI values among adolescents classified as underweight were overestimated by $5.35 \mathrm{~kg} / \mathrm{m}^{2}$ and $2.68 \mathrm{~kg} / \mathrm{m}^{2}$ between girls and boys, respectively.

Table 2 shows that the agreement was excellent for weight measures and adequate for height in both genders, according to the

Table 1 - Medians (P25 and P75) of errors in measures of weight, height, and Body Mass Index (BMI) according to sex and age. Piracicaba, São Paulo, Brazil, 2004.

Tabela 1 - Medianas (P25 e P75) dos erros de medida de peso, estatura e índice de massa corporal (IMC) de acordo com o sexo e idade. Piracicaba, São Paulo, Brasil, 2004.

\begin{tabular}{|c|c|c|c|c|c|c|}
\hline \multirow[t]{2}{*}{ Age (Years) } & \multicolumn{2}{|c|}{ Weight (kg) } & \multicolumn{2}{|c|}{ Height $(\mathrm{cm})$} & \multicolumn{2}{|c|}{ BMI $\left(\mathrm{kg} / \mathrm{m}^{2}\right)$} \\
\hline & Boys & Girls & Boys & Girls & Boys & Girls \\
\hline $10-14$ & $\begin{array}{c}-1.00 \\
(-3.00 ; 0.00)^{a}\end{array}$ & $\begin{array}{c}-1.00 \\
(-2.00 ; 0.00)^{a}\end{array}$ & $\begin{array}{c}-3.00( \\
-7.00 ; 1.00)^{\mathrm{a}}\end{array}$ & $\begin{array}{c}-2.00 \\
(-6.00 ; 1.00)^{a . b}\end{array}$ & $\begin{array}{c}.21 \\
(-1.59 ; 1.98)\end{array}$ & $\begin{array}{c}.01 \\
(-1.02 ; 1.11)\end{array}$ \\
\hline $10(n=79)$ & $\begin{array}{c}-1.00 \\
(-3.00 ; 0.75)^{\mathrm{a}}\end{array}$ & $\begin{array}{c}-1.00 \\
(-1.81 ; 0.00)^{\mathrm{a}}\end{array}$ & $\begin{array}{c}-2.00 \\
(-4.00 ; 1.00)\end{array}$ & $\begin{array}{c}-3.00 \\
(-6.00 ; 1.00)^{\mathrm{a}}\end{array}$ & $\begin{array}{c}.09 \\
(-2.05 ; 0.95)\end{array}$ & $\begin{array}{c}-.13 \\
(-1.02 ; 1.07)\end{array}$ \\
\hline $11(n=71)$ & $\begin{array}{c}-1.50 \\
(-3.56 ; 0.75)^{\mathrm{a}}\end{array}$ & $\begin{array}{c}-1.25 \\
(-2.50 ; 0.00)^{\mathrm{a}}\end{array}$ & $\begin{array}{c}-3.00 \\
(-7.00 ; 3.00)^{\mathrm{a}}\end{array}$ & $\begin{array}{c}-3.00 \\
(-10.00 ;-1.00)^{a}\end{array}$ & $\begin{array}{c}.32 \\
(-1.81 ; 3.07)\end{array}$ & $\begin{array}{c}.37 \\
(-1.02 ; 2.80)\end{array}$ \\
\hline $12(n=63)$ & $\begin{array}{c}-1.00 \\
(-2.25 ; 0.00)^{\mathrm{a}}\end{array}$ & $\begin{array}{c}-1.25 \\
(-3.00 ; 0.00)^{a}\end{array}$ & $\begin{array}{c}-6.00 \\
(-11.00 ;-1.00)^{\mathrm{a}}\end{array}$ & $\begin{array}{c}-3.00 \\
(-9.00 ; 2.00)^{\mathrm{a}}\end{array}$ & $\begin{array}{c}.96 \\
(-0.63 ; 2.87)\end{array}$ & $\begin{array}{c}.28 \\
(-0.48 ; 1.73)\end{array}$ \\
\hline $13(n=76)$ & $\begin{array}{c}-1.75 \\
(-5.63 ; 0.00)^{\mathrm{a}}\end{array}$ & $\begin{array}{c}-1.00 \\
(-2.00 ; 0.00)^{\mathrm{a}}\end{array}$ & $\begin{array}{c}-3.00 \\
(-7.00 ; 1.00)^{\mathrm{a}}\end{array}$ & $\begin{array}{c}-3.00 \\
(-7.00 ; 2.00)^{\mathrm{a}}\end{array}$ & $\begin{array}{c}-.25 \\
(-1.93 ; 1.87)\end{array}$ & $\begin{array}{c}-.36 \\
(-1.16 ; 1.11)\end{array}$ \\
\hline $14(n=71)$ & $\begin{array}{c}-1.00 \\
(-3.13 ; 1.00)\end{array}$ & $\begin{array}{c}-.63 \\
(-1.56 ; 0.56)\end{array}$ & $\begin{array}{c}-2.00 \\
(-5.00 ; 1.00)^{\mathrm{a}}\end{array}$ & $\begin{array}{c}.00 \\
(-2.00 ; 1.00)\end{array}$ & $\begin{array}{c}.29 \\
(-1.46 ; 1.30)\end{array}$ & $\begin{array}{c}-.34 \\
(-1.13 ; 0.66)\end{array}$ \\
\hline
\end{tabular}

a Significant differences according to the Wilcoxon test $(p<0.05)$ / Diferenças significantes de acordo com o teste de Wilcoxon $(p<0,05)$

${ }^{b}$ Significant differences according to the Kruskal Wallis test $(p<0.05)$ / Diferenças significantes de acordo com o teste de Kruskal Wallis $(p<0,05)$ 
Table 2 - Intra class Correlation Coefficient (ICC) ${ }^{\S}$ and 95\% Confidence Interval (CI) between self-reported and measured values of weight, height, and body mass index according to sex. Piracicaba, São Paulo, Brazil, 2004.

Tabela 2 - Coeficiente de correlação intraclasse (CCI) e Intervalo de confiança 95\% (IC) entre os valores auto-referidos e medidos de peso, estatura e índice de massa corporal de acordo com o sexo. Piracicaba, São Paulo, Brasil, 2004.

\begin{tabular}{lcccc}
\hline Measures & \multicolumn{3}{c}{ Boys } & \multicolumn{2}{c}{ Girls } \\
\cline { 2 - 5 } & ICC & Cl95\% & ICC & Cl95\% \\
\hline Weight $(\mathrm{kg})$ & 0.91 & $0.88-0.93$ & 0.91 & $0.89-0.93$ \\
Height $(\mathrm{cm})$ & 0.63 & $0.53-0.71$ & 0.63 & $0.54-0.71$ \\
BMI $\left(\mathrm{kg} / \mathrm{m}^{2}\right)$ & 0.52 & $0.40-0.62$ & 0.50 & $0.38-0.60$ \\
\hline
\end{tabular}

Obs: All intra class correlation coefficients are statistically significant $(p<0.05)$

Todos os coeficientes de correlação intraclasse são estatisticamente significantes $(p<0,05)$

classification proposed by Rosner ${ }^{14}$. Lower ICC values were observed for BMI, and according to the assessed kappa's weighted value of 0.52 for boys and 0.50 for girls, agreement can be classified as moderate, as proposed by Rosner ${ }^{14}$ and Masson et al..$^{15}$.

Overweight and obesity prevalences were $15.8 \%$ and $9.4 \%$ for boys and $12.2 \%$ and $16.5 \%$ for girls, respectively; based on self-reports, this prevalence was higher ( $17.0 \%$ and $25.7 \%$ for boys $v$ s. $13.8 \%$ and $20.6 \%$ for girls).

For boys, lower sensitivity was observed for identification of overweight (40.7\%) (Table 3). This index was higher for female adolescents (64.5\%) within the same category. In contrast, sensitivity to identification of obesity was higher among boys (87.5\%).

High BMI specificities were observed from the self-reported measures for boys and girls. Lower specificity was observed in the classification of normal-weight adolescents. Predictive positive value was higher only for classification of normal weight. For the remaining categories, this index was low, especially for girls.

Lin's agreement coefficients observed in boys and girls were 0.90 and 0.91 for weight, 0.60 and 0.61 for height, and 0.51 and 0.49 for BMI, respectively.

The average of differences was below zero, indicating a trend of weight underestimation by both genders. Pictures $1 \mathrm{~B}$ and $2 \mathrm{~B}$ show that height was underestimated by both genders; however, data were more scattered, and more subjects were outside the $95 \%$ limit of agreement when compared to weight data. In the Bland-Altman plot

Table 3 - Sensitivity, Specificity, and Positive Predictive Value (PPV) of BMI obtained from selfreported measures according to gender and nutritional status. Piracicaba, São Paulo, Brazil, 2004.

Tabela 3 - Sensibilidade, Especificidades e Valor Preditivo Positivo (VPP) de IMC obtido a partir das medidas auto-referidas de acordo com o sexo e estado nutricional. Piracicaba, São Paulo, Brasil, 2004.

\begin{tabular}{lcccccc}
\hline Nutritional Status & \multicolumn{3}{c}{ Boys } & \multicolumn{3}{c}{ Girls } \\
\cline { 2 - 6 } & Sensitivity & Specificity & PPV & Sensitivity & Specificity & PPV \\
\hline Underweight & - & $93.3 \%$ & - & $50.0 \%$ & $96.1 \%$ & $22.2 \%$ \\
Normal weight & $65.8 \%$ & $80.4 \%$ & $88.8 \%$ & $78.5 \%$ & $79.3 \%$ & $89.5 \%$ \\
Overweight & $40.7 \%$ & $88.1 \%$ & $39.3 \%$ & $64.5 \%$ & $87.9 \%$ & $51.3 \%$ \\
Obese & $87.5 \%$ & $80.6 \%$ & $31.8 \%$ & $60.9 \%$ & $92.7 \%$ & $53.8 \%$ \\
\hline
\end{tabular}

Obs: It was not possible to calculate because no adolescent was classified in that category

Não foi possivel calcular porque nenhum adolescente foi classificado nessa categoria 
for BMI (Figures 1C and 2C), fewer subjects were found outside the limits of agreement, presenting difference values closer to zero. The average of differences is higher than zero, indicating an overestimation of BMI.

In Figures 1 and 2 (D, E, and F), Lin's plots compare regression lines of the data with perfect agreement lines. For weight, (plots 1D and 2D), the straight line representing agreement between self-reported and measured areas is close to the perfect agreement line. However, for height and BMI (Charts E and F), data are more scattered and, therefore, further away from perfect agreement.

\section{Discussion}

When we compared reported and assessed data, we saw a trend for underestimating weight and height in both genders, which was higher in obese adolescents regarding weight (up to $6 \mathrm{~kg}$ ) and in underweight subjects regarding height (up to $5.9 \mathrm{~cm}$ for boys and $3.9 \mathrm{~cm}$ for girls). These values were higher than those presented in other studies ${ }^{1,6-8}$, where tendencies to underestimate weight (from 0.5 to $2.6 \mathrm{~kg}$ ), and to overestimate height (from 0.1 to $0.8 \mathrm{~cm}$ ) were observed.

Abraham et al. ${ }^{1}$ and Peixoto et al. ${ }^{16}$
(A

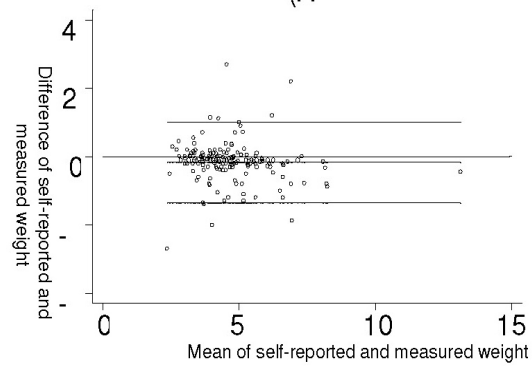

$(B$

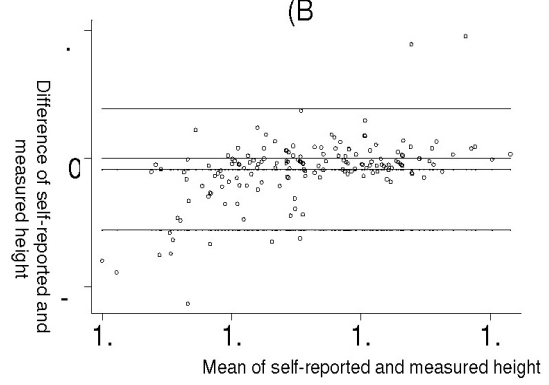

$(\mathrm{C}$

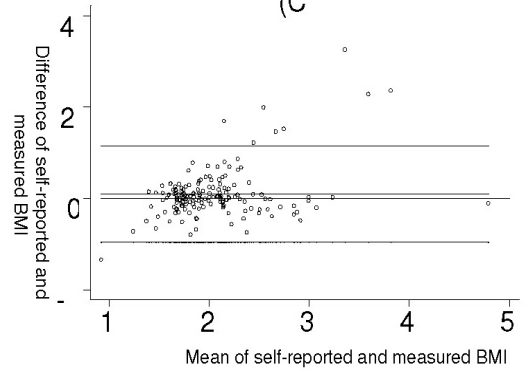

$(\mathrm{D}$

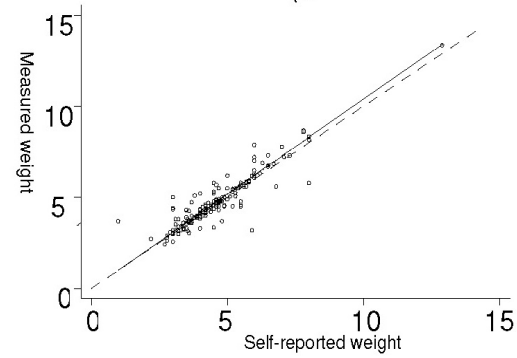

$(\mathrm{E}$

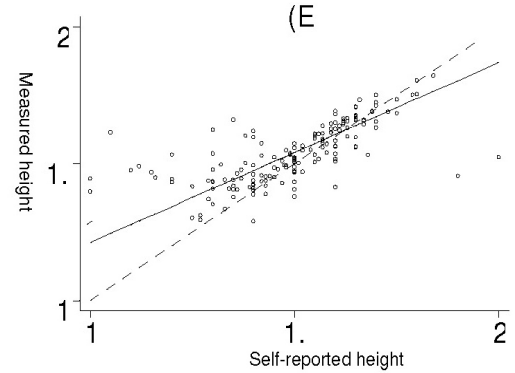

(F)

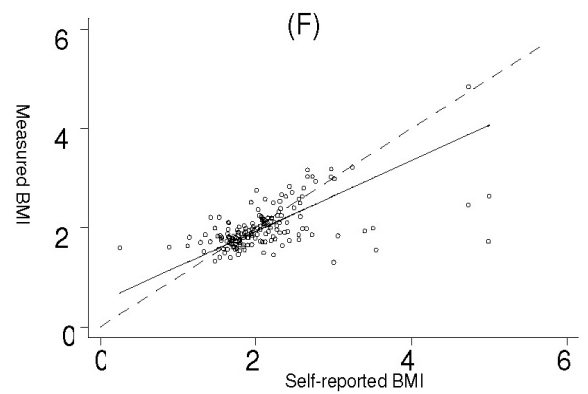

OBS: The dashed line in graphs $D, E, F$ is the line of perfect agreement.

A linha tracejada nos gráficos $D, E$, Fé a linha de concordância perfeita.

Figure 1 - Bland \& Altman (A, B, C) and Lin (D, E, F) Plots for weight, height, and BMI for boys. Piracicaba, Sao Paulo, Brazil, 2004.

Figura 1 - Gráficos de Bland \& Altman $(A, B, C)$ e Lin $(D, E, F)$ para peso, estatura e IMC para meninos. Piracicaba, São Paulo, Brasil, 2004 
(A
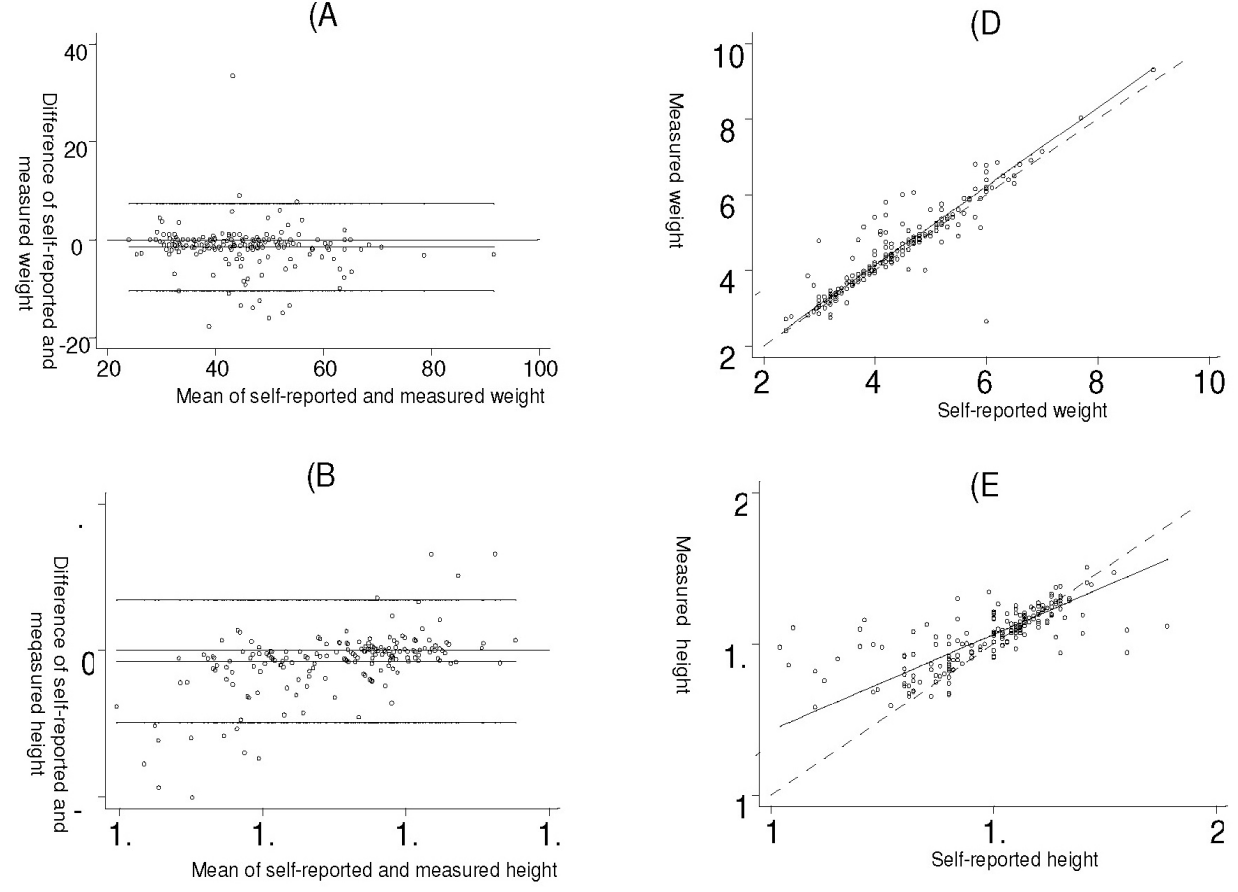

$(\mathrm{C}$

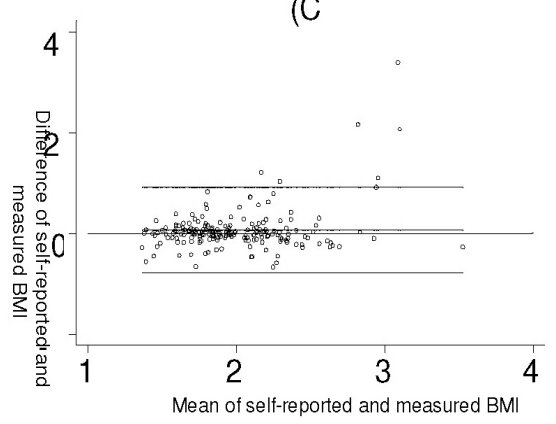

(F

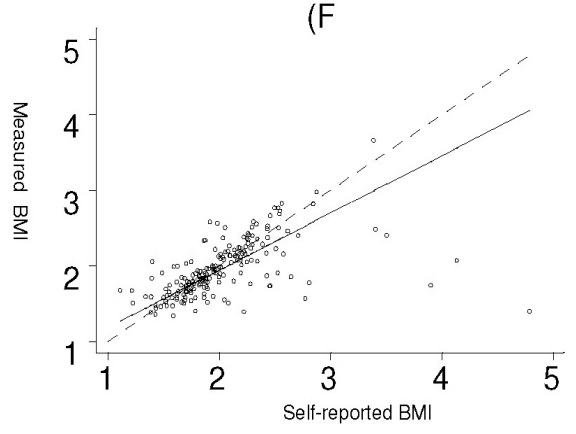

OBS: The dashed line in graphs $D, E, F$ is the line of perfect agreement.

A linha tracejada nos gráficos $D, E$, F é a linha de concordância perfeita.

Figure 2 - Bland \& Altman (A, B, C) and Lin (D, E, F) Plots for weight, height, and BMI for girls. Piracicaba, São Paulo, Brazil, 2004.

Figura 2 - Gráficos de Bland \& Altman $(A, B, C)$ e Lin $(D, E, F)$ para peso, estatura e IMC para meninas. Piracicaba, São Paulo, Brasil, 2004.

showed that age, height, and current weight, schooling, income, the frequency these data are assessed, sexual maturity, time elapsed since first period, practicing physical activity, and cultural and psychological aspects can interfere with the accuracy of reporting those measures. Ambrosi-Randic \& Bulian ${ }^{6}$ also reinforce the role of lack of information on weight and height. Wang et al. ${ }^{17}$ and Tokmakidis et al. ${ }^{8}$ did not see any effect of gender on the accuracy of anthropometric measures.
Other sources for errors are adopting inadequate procedures (i.e., heavy clothes and shoes), using non calibrated instruments, and adolescents assessing their own measures $^{7}$. We must also consider the possibility that adolescents assess their measures very rarely, having outdated information because of their fast growth ${ }^{5,7}$.

Elgar et al. ${ }^{18}$, assessing data of 418 adolescents from 15 to 17 years of age, found significant underestimation of weight among 
girls and of BMI for both genders and did not find significant differences for self-report errors in weight, height, and BMI among boys and girls.

In this study, sensitivity to estimate BMI based on reported measures to classify obese subjects was higher for boys (87.5\%) than for girls (60.9\%). Thus, one in every ten boys and four in every ten girls are no longer classified in this category. These values were higher than those found by Rasmussen et al. ${ }^{19}$, but similar to those of Farias Júnior ${ }^{7}$, who assessed the sensitivity of subjects classified as overweight/obese together. The low sensitivity, defined as the ability to identify truly obese subjects among those that are reported as obese using reference measures, may have undesirable consequences for health tracking programs in students. However, when the presence of false negatives is not a real problem, such as in long-term surveillance and trend studies, the use of estimated BMI based on reported measures is a less expensive alternative ${ }^{19}$.

Specificity was higher for girls $(92.7 \%)$ compared to boys (80.6\%), consistent with other studies ${ }^{19,20}$. The capacity of estimated BMI based on reported measures to diagnose non-obese adolescents was satisfactory, since nine of ten adolescents that were not obese were correctly classified. This finding is consistent with other investigations ${ }^{7,17,18}$.

Positive predictive value was lower than that observed in other reports with adolescents $^{7,21}$. Among adolescents classified as obese, only three in every ten boys and five in every ten girls presented this condition. Goodman \& Strauss ${ }^{22}$ showed that the weight of overweight children is usually 27 $\mathrm{kg}$ higher than of non-obese children, with little likelihood that a 2.7 to $5.4 \mathrm{~kg}$ error due to bias in the report will make a difference in classification using a cut-off point of $95 \%$. Those subjects classified incorrectly tend to be within the classification limits and, therefore, have the same risk factors.

Among boys, the use of self-reported measures overestimated the prevalence of obesity by $16.3 \%$ (9.4\% assessed vs. $25.7 \%$ self-reported).
Elgar et al. ${ }^{18}$ observed an underestimation of overweight and obesity prevalence when self-reported data was used due to the underreporting of weight by adolescents. These findings are in contrast with results of this study. Peixoto et al. ${ }^{16}$ justified that the possible overestimation of height may reinforce a systematic error towards a cultural standard that values being tall and slim.

Findings by Lee et al. ${ }^{23}$ are similar to those presented in this study for measures of weight in both genders (since excellent agreement has been found), for height in boys, and for BMI in girls. In contrast, compared with another research ${ }^{7}$, only ICC of weight measures in both genders was similar. Rasmussen et al. ${ }^{19}$ reported weighted Kappa's coefficient values $(k>0.70)$ higher than those found in this study, although they used another reference to classify nutritional status.

This study has some limitations. First, the lack of information about the place where anthropometric measures were assessed the previous time, the time elapsed since last assessment, and the procedures and types of equipments used before the interview may have contributed to obtaining less reliable data. Despite these limitations, a positive aspect was the fact that participants did not know the objective of the comparison between measured and self-reported data.

In summary, findings of this study suggest that self-reported measures should not be used to replace measured ones in adolescents, since only weight presented adequate validity. Diagnoses of nutritional status of adolescents using self-reported data of weight and height cannot be reliably conducted, especially in girls.

Population studies intending to use selfreported anthropometric measures must assess weight and height measures in a sub-sample to assess the error size and thus to correct these data, which would simplify fieldwork, making it fast and less expensive.

Acknowledgements: This study was supported by The State of Sao Paulo Research Foundation (FAPESP) (Grant n. 02/9521-9). 


\section{References}

1. Abraham S, Luscombe G, Boyd C, Olesen I. Predictors of the accuracy of self-reported height and weight in adolescent female school students. Int J Eat Disord 2004; 36: 76-82.

2. Fisberg M. Primeiras palavras: uma introdução ao problema do peso excessivo. In: Atualização em obesidade na infância e adolescência. São Paulo: Atheneu; 2005. p. 1-10.

3. Queiroga MR. Avaliação da composição corporal. In: Testes e medidas para avaliação da aptidão física relacionada à saúde em adultos. Rio de Janeiro: Guanabara Koogan; 2005. p. 5-54.

4. Gorber SC, Tremblay M, Moher D, Gorber B. A comparison of direct vs. self-report measures for assessing height, weight and body mass index: a systematic review. Obes Rev 2007; 8:307-26.

5. Himes JH, Hannan P, Wall M, Neumark-Sztainer D. Factors associated with errors in self-reports of stature, weight, and Body Mass Index in Minnesota adolescents. Ann Epidemiol 2005; 15: 272-8.

6. Ambrosi-Randic N, Bulian AP. Self-reported versus measured weight and height by adolescent girls: a Croatian sample. Percept Mot Skills 2007; 104: 79-82.

7. Farias Júnior JC. Validity of self-reported weight and height for adolescent nutritional status diagnosis. Braz J Mother Child Health 2007; 7: 167-74.

8. Tokmakidis SP, Christodoulos AD, Mantzouranis NI. Validity of self-reported anthropometric values used to assess Body Mass Index and estimate obesity in Greek school children. J Adolesc Health 2007; 40: 305-10.

9. Toral N, Slater B, Silva MV. Food consumption and overweight in adolescents from Piracicaba, Sao Paulo, Brazil. J Nutr 2007; 20: 449-59.

10. Lohman TG, Roche AF and Martorell R (eds.). Anthropometric standardization reference manual. Champaign (IL): Human Kinetics Books; 1988.

11. De Onis M, Onyango AW, Borghi E, Siyam A, Nishida C, Siekmann J. Development of a WHO growth reference for school-aged children and adolescents. Bull World Health Organ 2007; 85: 660-7.

12. Bland JM, Altman DG. Measuring agreement in method comparison studies. Stat Methods Med Res 1999; 8: 13560 .
13. Lin LI. A concordance correlation coefficient to evaluate reproducibility. Biometrics 1989; 45: 255-68.

14. Rosner B. Fundamentals of Biostatistics (4th ed.). Belmont (CA): Wadsworth Publishing Co; 1995.

15. Masson LF, McNeill G, Tomany JO, Simpson JA, Peace HS, Wei L et al. Statistical approaches for assessing the relative validity of a semi-quantitative food frequency questionnaire: use of correlation coefficients and the Kappa statistic. Publ Health Nutr 2003; 6: 313-21.

16. Peixoto MRG, Benício MHDA, Jardim PCBV. Validity of self-reported weight and height: the Goiânia study, Brazil. J Publ Health 2006; 40: 1065-72.

17. Wang Z, Patterson CM, Hills AP. A comparison of selfreported and measured height, weight and BMI in Australian adolescents. Aust N Z J Public Health 2002; 26 : 473-8.

18. Elgar FJ, Roberts C, Tudor-Smith C, Moore L. Validity of self-reported height and weight and predictors of bias in adolescents. J Adolesc Health 2005; 37: 371-5.

19. Rasmussen F, Eriksson M, Nordquist T. Bias in height and weight reported by Swedish adolescents and relations to body dissatisfaction: the COMPASS study. Eur J Clin Nutr 2007; 61: 870-6.

20. Galán I, Gandarillas A, Febrel C, Meseguer CM. Validación del peso y talla autodeclarados en población adolescente. Gac Sanit 2001; 15: 490-7.

21. Brener ND, McManus T, Galuska DA, Lowry R, Wechsler $H$. Reliability and validity of self-reported height and weight among high school students. J Adolesc Health 2003; 32: 281-7.

22. Goodman E, Strauss RS. Self-reported height and weight and the definition of obesity in epidemiological studies. JAdolesc Health 2003; 33: 140-2.

23. Lee K, Valeria B, Kochman C, Lenders CM. Selfassessment of height, weight, and sexual maturation: validity in overweight children and adolescents. $J$ Adolesc Health 2006; 39: 346-52.

Recebido em: 23/04/09 Versão final reapresentada em: 09/09/09 Aprovado em: 28/09/09 